Research Paper

\title{
Non-immunosuppressive triazole-based small molecule induces anticancer activity against human hormone-refractory prostate cancers: the role in inhibition of PI3K/AKT/mTOR and c-Myc signaling pathways
}

\author{
Wohn-Jenn Leu ${ }^{1, *}$, Sharada Prasanna Swain ${ }^{2, *}$, She-Hung Chan ${ }^{1}$, Jui-Ling Hsu ${ }^{1}$, \\ Shih-Ping Liu ${ }^{3}$, Mei-Ling Chan ${ }^{1}$, Chia-Chun $\mathbf{Y u}^{1}$, Lih-Ching Hsu ${ }^{1}$, Yen-Lin Chou ${ }^{2}$, \\ Wei-Ling Chang ${ }^{1}$, Duen-Ren Hou' ${ }^{2}$, Jih-Hwa Guh ${ }^{1}$ \\ ${ }^{1}$ School of Pharmacy, National Taiwan University, Taipei, Taiwan \\ ${ }^{2}$ Department of Chemistry, National Central University, Jhong-li, Taoyuan, Taiwan \\ ${ }^{3}$ Department of Urology, National Taiwan University Hospital, Taipei, Taiwan \\ *These authors contributed equally to this work \\ Correspondence to: Duen-Ren Hou, email: drhou@cc.ncu.edu.tw \\ Jih-Hwa Guh, email: jhguh@ntu.edu.tw \\ Keywords: triazole-base, non-immunosuppression, PI3K/Akt/mTOR signaling, Myc, autophagy \\ Received: May 15, 2016 Accepted: October 14, $2016 \quad$ Published: October 19, 2016
}

\section{ABSTRACT}

A series of triazole-based small molecules that mimic FTY720-mediated anticancer activity but minimize its immunosuppressive effect have been produced. SPS-7 is the most effective derivative displaying higher activity than FTY720 in anti-proliferation against human hormone-refractory prostate cancer (HRPC). It induced $\mathrm{G1}$ arrest of cell cycle and subsequent apoptosis in thymidine blockmediated synchronization model. The data were supported by a decrease of cyclin D1 expression, a dramatic increase of p21 expression and an associated decrease in RB phosphorylation. C-Myc overexpression replenished protein levels of cyclin D1 indicating that c-Myc was responsible for cell cycle regulation. PI3K/Akt/mTOR signaling pathways through p7056K- and 4EBP1-mediated translational regulation are critical to cell proliferation and survival. SPS-7 significantly inhibited this translational pathway. Overexpression of Myr-Akt (constitutively active Akt) completely abolished SPS-7-induced inhibitory effect on $\mathrm{mTOR} / \mathrm{p70S6 \textrm {K } / 4 E B P 1}$ signaling and c-Myc protein expression, suggesting that PI3K/Akt serves as a key upstream regulator. SPS-7 also demonstrated substantial anti-tumor efficacy in an in vivo xenograft study using PC-3 mouse model. Notably, FTY720 but not SPS-7 induced a significant immunosuppressive effect as evidenced by depletion of marginal zone B cells, downregulation of sphingosine-1-phosphate receptors and a decrease in peripheral blood lymphocytes. In conclusion, the data suggest that SPS-7 is not an immunosuppressant while induces anticancer effect against HRPC through inhibition of Akt/mTOR/ p7056K pathwaysthat down-regulate protein levels of both c-Myc and cyclin D1, leading to $\mathbf{G 1}$ arrest of cell cycle and subsequent apoptosis. The data also indicate the potential of SPS-7 since PI3K/Akt signalingis responsive for the genomic alterations in prostate cancer.

\section{INTRODUCTION}

Carcinoma of the prostate is one of the most frequently diagnosed cancers and leading causes of cancer death in men. Hormone-refractory prostate cancer (HRPC) is a type of progressive prostate cancer unresponsive to hormone therapy and is one of the major hurdles in clinical oncology although several cancer chemotherapeutic drugs have been developed for clinical treatment $[1,2]$. Maximizing treatment options, in particular in longterm surviving patients with decreased disease burden, is of importance. Four pathways are well identified to be 
responsive for the genomic alterations in prostate cancer that challenges the conversion of localized to androgenindependent metastatic cancers, including phosphoinositide 3-kinase (PI3K) signaling, androgen receptor pathway, rearrangements placing E26 transformation-specific transcription factor family through androgen responsive promoter transmembrane protease serine 2(TMPRSS2) and loss of function of prostate-specific tumor suppressor NKX3.1 [2]. PI3K/Akt is the most extensively investigated pathway in prostate cancer since its involvement is not only clearly identified in localized prostate cancers but also is increased in HRPCs [3, 4]. PI3K/Akt and associated mTOR pathways are responsible for cell survival, growth, metastasis and both chemo- and radio-resistances in prostate cancer and other cancers. Targeting this pathway by inhibitors to increase both chemo- and radio-sensitivities may have great potential in clinical benefits $[4,5]$.

Sphingosine kinase (SK), a conserved lipid kinase, catalyzes the ATP-dependent formation of sphingosine1-phosphate (S1P) from the precursor sphingosine [6, 7]. SK1 and SK2 are two major forms found in the cytosol and localized to the nucleus, respectively. S1P may serve as an inducer to regulate diverse cellular functions of cell growth and survival through binding to S1P receptors. It also functions as an intracellular second messenger and a key mediator in cytokine network [6-8]. Recently, targeting the $\mathrm{SK} / \mathrm{S} 1 \mathrm{P} / \mathrm{S} 1 \mathrm{P}$ receptor signaling pathway has been considered as a potential anticancer therapeutic strategy [9]. FTY720, a structural analogue of sphingosine and S1P receptor agonist approved by FDA, is developed as a first line oraldrug of multiple sclerosis through immunemodulating effect [10]. In recent decade, a considerable number of studies have been conducted on FTY720induced anticancer effect through diverse pathways, including inhibition of histone deacetylase [11], activation of protein phosphatase 2A [12], inhibition of STAT3 signaling [13], up-regulation of death receptor mediating signaling [14] and other pathways [15-18]. Although FTY720 displays immunosuppressive effects through activating S1P receptors, phosphorylation of FTY720 is not necessary to its anticancer activity in numerous cases suggesting the participation of S1P receptor-independent pathways [19]. However, several adverse effects occur to FTY720 treatment $[20,21]$. Cardiovascular effects are one of the concerns because of the presence of S1P receptors in the sinus and atrioventricular nodes, myocardial cells, endothelial cells and arterial smooth muscle cells [20]. Therefore, the preservation of anticancer activity but decreasing S1P receptor-dependent immunosuppression is challenging in developing FTY720 analogues.

The introduction of phenylene moiety in a proper position of FTY720 is highly critical for its potent immunosuppressive activity [22]. Therefore, several compounds have been produced after displacing the phenylene ring with other ring moiety and the modification of side chain length (Table 1). SPS-7 (1,3-Dihydroxy-2-((1-
octadecyl-1H-1,2,3-triazol-4-yl)methyl)propan-2-aminium chloride) is the most effective derivative and the synthetic scheme has been demonstrated (supplementary Scheme I). The signaling of SPS-7 on PI3K/Akt/mTOR/c-Myc pathways and the immune-modulating activitieshave been studied to demonstrate its anticancer potential against HRPC.

\section{RESULTS}

\section{SPS-7 inhibits cell proliferation and induces apoptosis in HRPC cells}

Sulforhodamine B colorimetric assay was used to examine the effect on cell proliferation. Both SPS-7 and FTY-720 inhibited cell proliferation with $\mathrm{IC}_{50}$ values of $2.98 \pm 0.12$ v.s. $3.26 \pm 0.37 \mu \mathrm{M}$ in PC-3 cells, $4.63 \pm$ 0.15 v.s. $6.10 \pm 0.55 \mu \mathrm{M}$ in DU-145 cells, and $2.61 \pm$ 0.10 v.s. $3.29 \pm 0.12 \mu \mathrm{M}$ in LNCaP cells, respectively (Figure 1A). The data also showed that the concentration at $10 \mu \mathrm{M}$ caused a total growth inhibition (cytotoxicity) in these cancer cells. In contrast, the anti-proliferative $\mathrm{IC}_{50}$ of SPS-7 in primary prostate cells was $7.0 \pm 0.12$ $\mu \mathrm{M}$. The concentrations that caused a total growth inhibition were much higher than $30 \mu \mathrm{M}$ (Figure 1A). The data indicated the anticancer selectivity of SPS-7. Cell proliferation was further examined in PC-3 cells by CFSE staining, a cell-tracking dye which conjugated to intracellular proteins and was evenly inherited by divided cells after cell proliferation. As a result, the fluorescence-staining was distributed to later generations of the cells with the passage of time (Figure 1B). SPS7 significantly inhibited cell proliferation, resulting in a profound increase of cell population in earlier generations (Figure 1B). Furthermore, the proliferation index based on the CFSE staining assay was determined showing that the control indexes at 48 and $72 \mathrm{~h}$ were $5.7 \pm 0.2$ and $9.7 \pm 0.5$, respectively. SPS-7 significantly slowed down the cell proliferation with the indexes of $4.2 \pm 0.2$ and $4.7 \pm 1.0$, respectively $(P<0.001, n=3)$.

\section{SPS-7 induces G1 arrest of the cell cycle and controls the expression dynamics of cell cycle regulator proteins}

Thymidine overload in thymidine block assayhalted the DNA replication and synchronized PC-3 cells mainly at late $\mathrm{G} 1$ and $\mathrm{S}$ phases. After the release from thymidine block, the cells proceeded through the stages of cell cycle with the majority at G2/M phase and G1 phase after the release for $8 \mathrm{~h}$ and $12 \mathrm{~h}$, respectively (Figure 2A). Both SPS-7 and FTY-720 retarded the progression of cell cycle and, once the cells progressed into G1 phase, the cell cycle was arrested and the population at sub-G1 phase (apoptosis) was subsequently increased (Figure 2A). The quantitative data also demonstrated the sustained high levels of G1 phase population and the increases of apoptosis under 


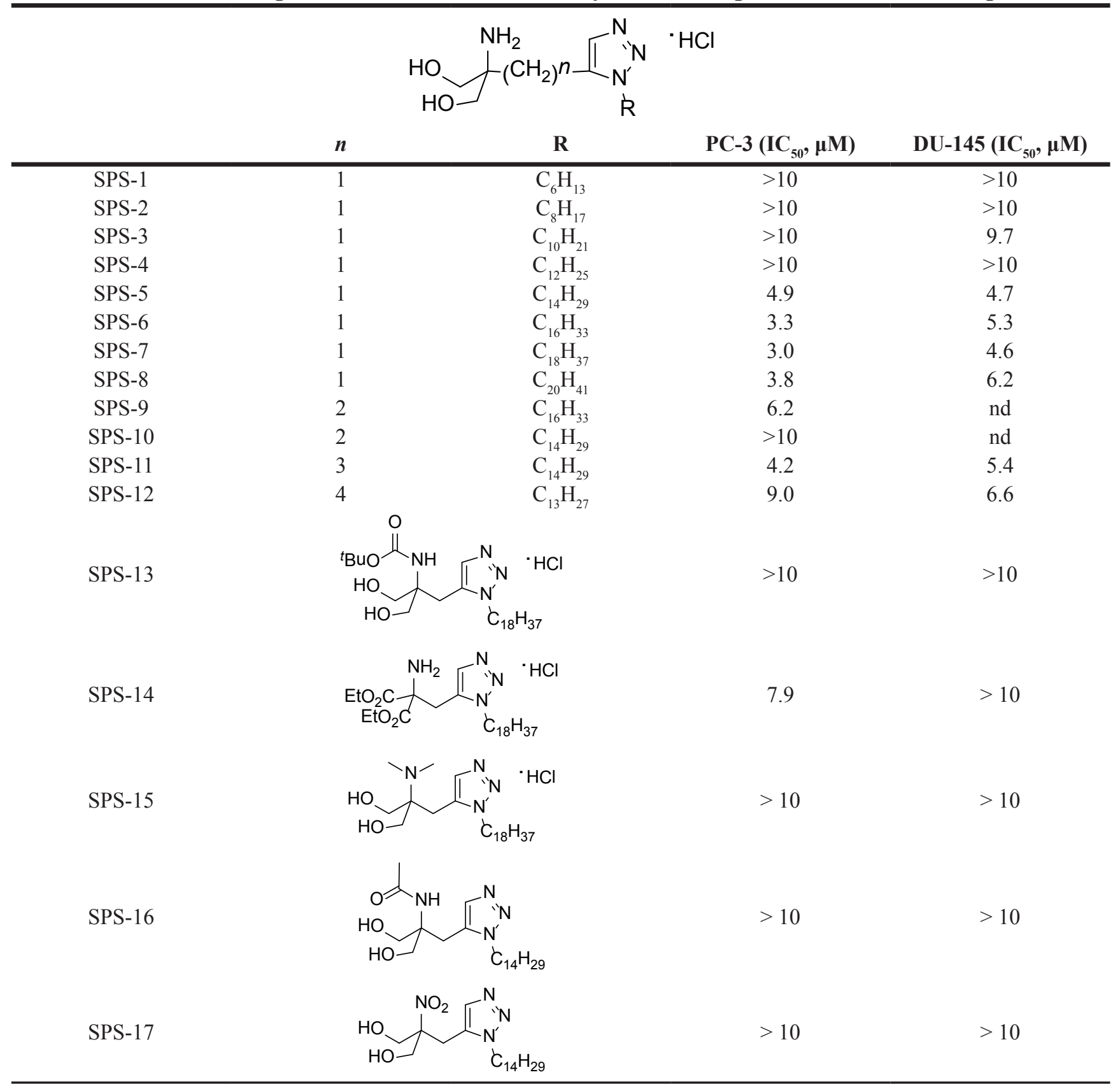

Cells were incubated in the absence or presence of the compound 48 hours. The cell proliferation was determined using sulforhodamine B assay.

the exposure to SPS-7 and FTY-720 (Figure 2B). Similar effects on G1 arrest were obtained in DU-145 cells (control of $46.8 \pm 2.2 \%$ compared with $60.2 \pm 1.2 \%$ and $57.6 \pm 0.9 \%$ for SPS-7 and FTY-720, respectively; $P<0.001, n=3$ ). The concentration- and time-dependent apoptosis were induced in both PC-3 and DU-145 cells (Figure 2C).

Cell cycle progression is regulated by periodic activation of several $\mathrm{Cdk} /$ cyclin complexes. Cyclin D1 interacts with Cdk4 forming a complex that prompts the cells entering G1 phase. SPS-7-induced decrease inthe protein expression of cyclin D1 but notthe other cyclins correlated to $\mathrm{G} 1$ arrest (Figure $3 \mathrm{~A}$ ). Rb, a tumor suppressor responsible to G1 checkpoint, impedes an entry into $\mathrm{S}$ phase of the cell cycle. Cyclin D1/Cdk4 complex inhibits $\mathrm{Rb}$ by appropriate phosphorylation andreduces its association with E2F transcription factor, leading tothe activation of downstream gene transcription [23]. p21, the endogenous $\mathrm{Cdk}$ inhibitor, binds and inhibits the activities of cyclin D1/Cdk4 complexes and blocks the transition from $\mathrm{G} 1$ into $\mathrm{S}$ phase $[24,25]$. As a consequence, SPS-7 decreased the level of $\mathrm{Rb}$ phosphorylation and dramatically increased p21 protein expression. The data agreed with 
the effects on G1 arrest and decreased level of cyclin D1 (Figure 3A). Notably, SPS-7 decreased the expression of c-Myc, an oncoprotein discovered to participate in many cellular functions including cell proliferation, apoptosis and transformation [26, 27]. c-Myc may collaborate with several growth factors and kinases in regulating cyclin D1 expression. Therefore, it is suggested that targeting c-Myc and cyclin D1 may be a good anticancer strategy [26, 28].

A

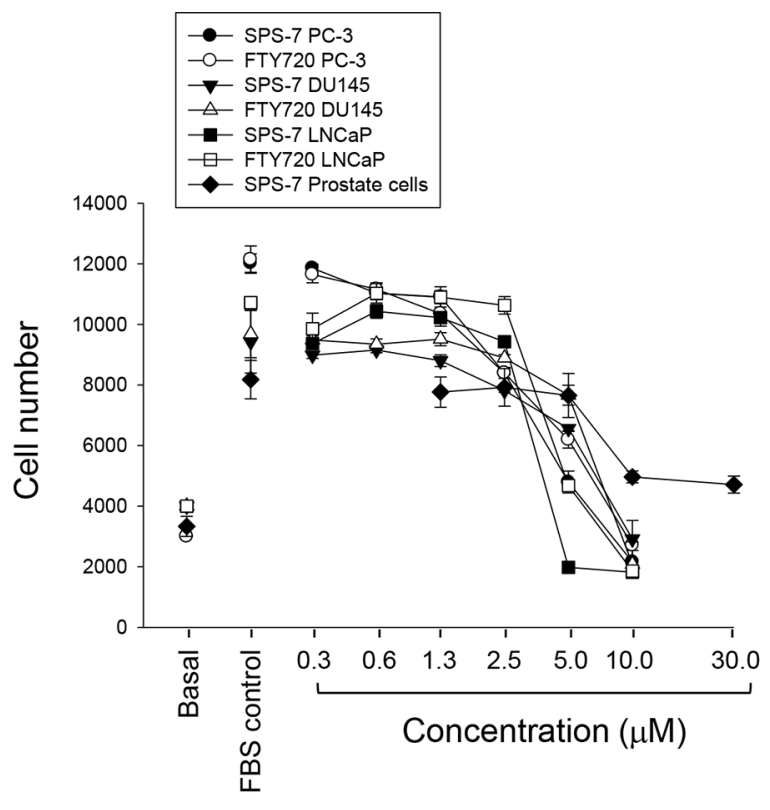

B
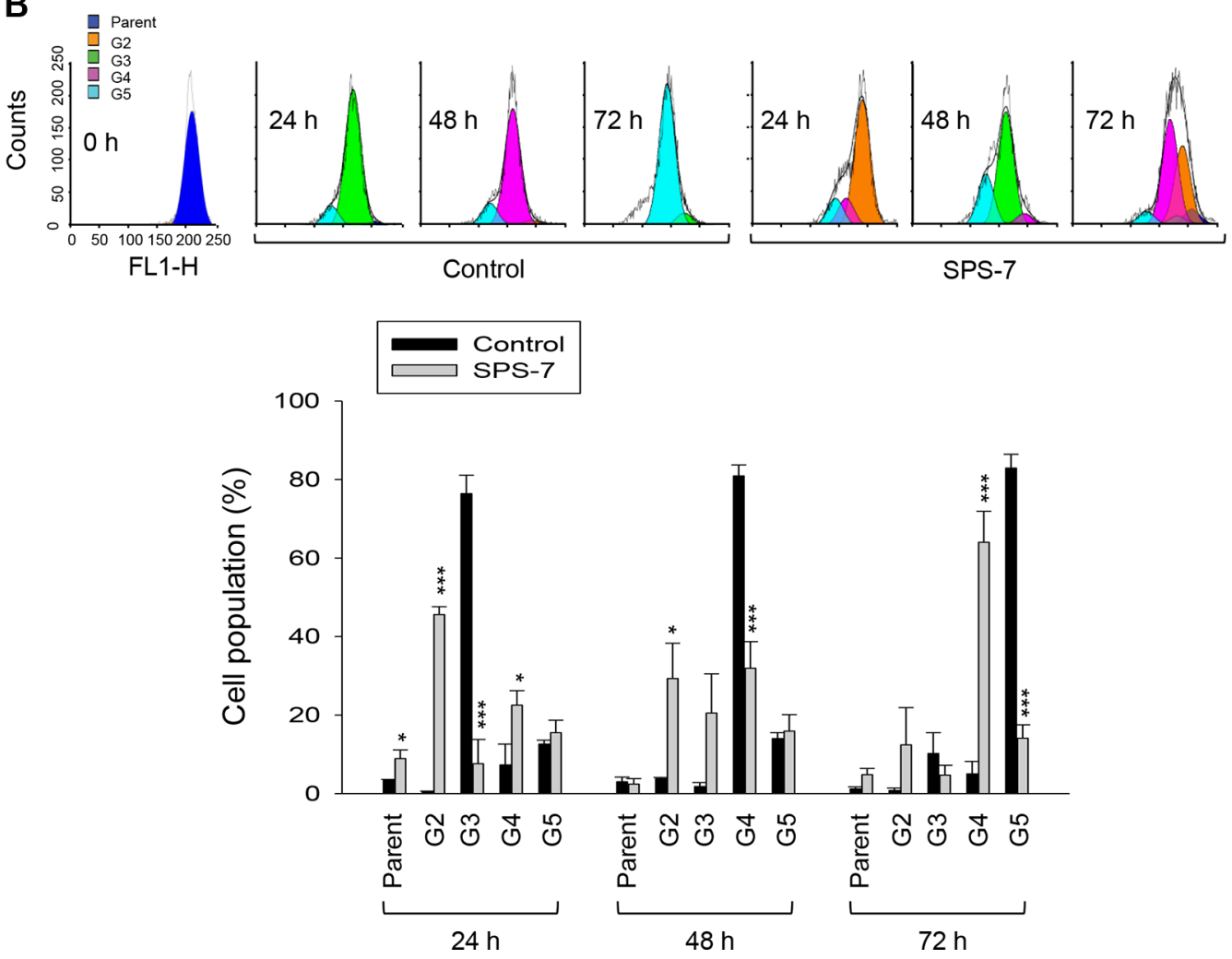

Figure 1: SPS-7 inhibits cell proliferation in human prostate cancer cells. (A) Cells were incubated in the absence or presence of SPS-7 for $48 \mathrm{~h}$ in PC-3 cells and $72 \mathrm{~h}$ in DU145, LNCaP and primary prostate cells. After the treatment, cell proliferation was determined using sulforhodamine B assay. Basal, seeding cell numbers. (B) PC-3 cells were incubated in the absence or presence of SPS-7 (10 $\mu \mathrm{M})$ for the indicated time. After treatment, the cells were harvested for flow cytometric analysis of CFSE staining. The cell proliferation was to be followed by monitoring decrease in label intensity in successive daughter cell generations. The proliferation index and the cell populations of parent or different generations were calculated by Modfit LT Version 3.2 and WinList Version 5.0 software. Quantitative data are expressed as mean \pm SEM of three to four independent experiments. $* P<0.05$ and $* * * P<0.001$ compared with the control. 
However, the role of c-Myc on cyclin D1 expression needs further clarification (please see below).

\section{SPS-7 inhibits the activation of Akt/mTOR pathway}

A variety of reports have suggested the importance of the PI3K/Akt/mTOR pathway through p70S6Kand 4EBP1-mediated translational regulation on cell proliferation and survival [3-5, 29]. The data demonstrated the activities on the Akt/mTOR signaling including the phosphorylation of Akt at both Thr308 and Ser473 residues in the activation loop and hydrophobic motif of the kinase, respectively, and phosphorylation of mTOR at Ser2448 that was dependent on the kinase activity (Figure 3B) [30, 31]. Furthermore, phosphorylation of p70S6K was detected at both Thr421/Ser424 and Thr389 that were required in cooperation to achieve full

A
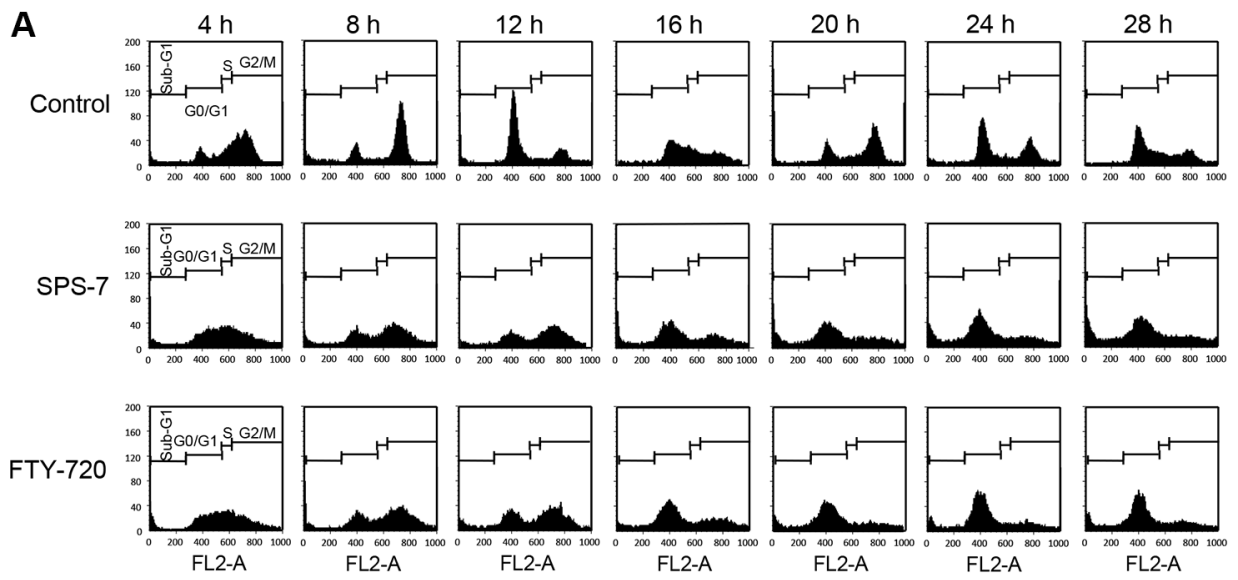

B
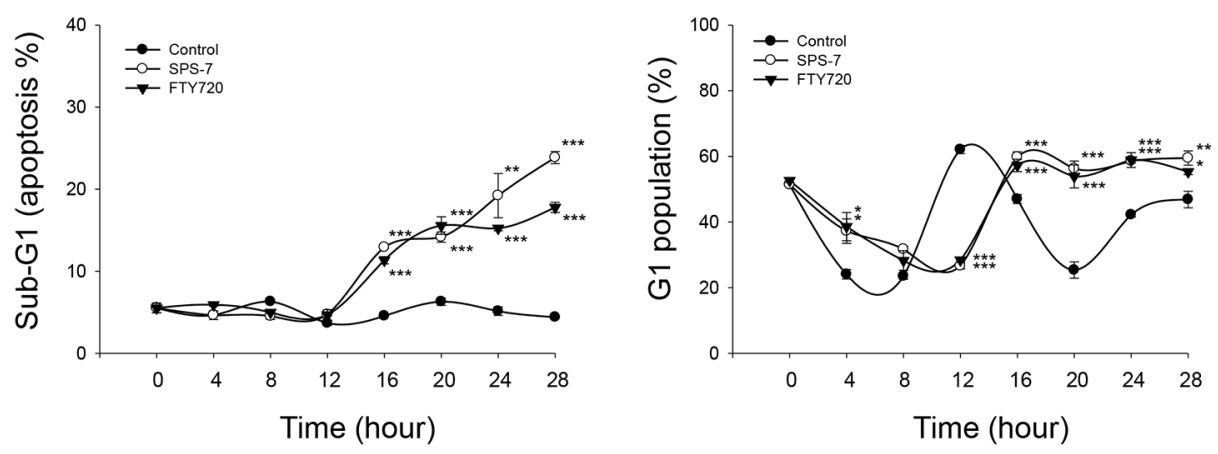

C
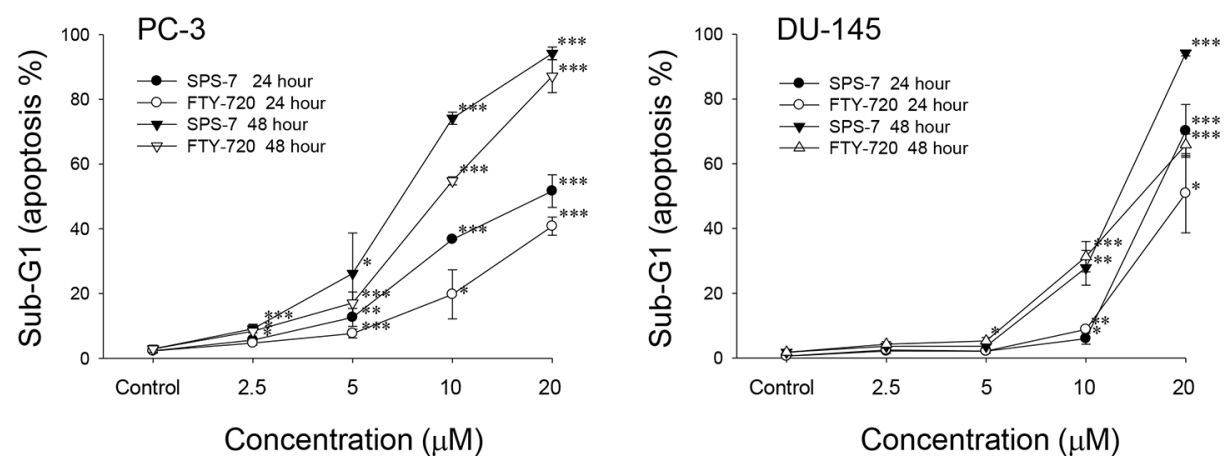

Figure 2: SPS-7 induces G1 arrest of the cell cycle and apoptosis. (A) Synchronization of PC-3 cells was performed by thymidine block as described in the Materials and Methods section. Then, the cells were released in the absence or presence of $10 \mu \mathrm{M}$ SPS-7 or FTY720 for the indicated times. Data are representative of three independent experiments. (B) Quantitative data are expressed as mean \pm SEM of three independent experiments. (C) PC-3 or DU-145 cells were incubated in the absence or presence of the compound $(10 \mu \mathrm{M})$ for 24 or 48 hours. After the treatment, the cells were harvested for the determination of sub-G1 population using the detection of DNA content analyzed with FACScan and CellQuest software. Data are expressed as mean \pm SEM of three independent determinations. $* P<0.05, * * P<0.01$ and $* * * P<0.001$ compared with the respective control. 
kinase activation [32]. Phosphorylation of the translation repressor, 4EBP1, was also apparent at both Thr37/46 and Thr70, which were necessary for removing this repressor protein (Figure 3B) [33]. Consequently, SPS-7 showed a promising inhibition on these signaling pathways as evidenced by the inhibition of phosphorylation on the mentioned kinases and proteins (Figure 3B). Furthermore, SPS-7 induced the cleavage of caspases such as caspase-9, caspase-7 and PARP-1 (a substrate of caspase-3 and -7), indicating the caspase-dependent apoptosis (Supplementary Figure S1).

\section{c-Myc and Akt signals interactively regulate downstream pathways}

c-Myc may collaborate with several receptors of growth factors, Ras/Raf mitogen-activated protein kinases cascade and PI3K/Akt through coordination in regulating cyclin D1 expression [26, 28, 34]. To determine the functional roles of c-Myc and Akt, plasmid transfection was performed and the effects on protein levels were examined using Western blot analysis. The data demonstrated that the cells transfected with c-myc expressed high levels of c-Myc protein, leading to the replenishment of cyclin D1 protein but not the other protein phosphorylation under the exposure to SPS-7 (Figure 4A). The data were verified by the knockdown of c-myc that led to the down-regulation of cyclin D1 protein expression (data not shown). The data revealed that c-Myc served as an upstream regulator on cyclin D1 dynamics. In contrast, overexpression of constitutively active Myr-Akt in the cells counteracted SPS-7-induced effects, including the induction of p21 protein expression and inhibitory effects of both c-Myc and cyclin D1 protein levels and the phosphorylation of Rb and mTOR pathway related proteins (Figure 4B). The parallel experiments also demonstrated that MK2206, an Akt inhibitor, exhibited similar effects to SPS-7 (data not shown). The data suggest that Akt functions as a key regulator on c-Myc expression and mTOR translational pathway.

\section{SPS-7 induces cytoprotective autophagy counteracting cell apoptosis}

Autophagy, a ubiquitous self-cannibalization process on cellular organelles or proteins degraded and recycled through autophagosomes and lysosomes, may show cytoprotective effects to help maintain cell homeostasis or demonstrate another way to die $[35,36]$. The activities of Akt and mTOR kinases have been suggested to be mechanistically linked to autophagy inhibition and tumorigenesis [37]. SPS-7 that displayed an inhibitory activity on these kinase pathways might represent a fundamental mechanism underlying the regulation of autophagy. The data demonstrated that SPS-7 facilitated the conversion of LC3-I to LC3-II (a hallmark of autophagosome formation) and the degradation of p62/SQSTM1 (an adaptor protein required for recognizing/loading cargo into autophagosomes) (Figure 5A), indicating autophagy induction. Chloroquine, a lysosomotropic agent for the inhibition of autophagy, by itself had little effect on PC-3 cells but dramatically enhanced SPS-7-induced apoptosis and the loss of mitochondrial membrane potential (Figure 5B and 5C). The data suggest that the autophagy may drive a cytoprotective mechanism counteracting apoptotic stress.

\section{SPS-7 has negligible effect on S1PR and lymphocyte homing}

The S1PRs regulate a wide variety of biological processes including cell proliferation, migration, cytoskeleton organization, angiogenesis, endothelial cell chemotaxis, immune cell trafficking, mitogenesis and heart rate [38]. S1PRs areinvolved in immunemodulation and the suppression of innate immune responses from $\mathrm{T}$ cells. FTY720 is an S1PR modulators and immunosuppressor for the treatment of multiple sclerosis. Notably, recent studies show that FTY720 also induces anticancer activity in several cancer models through S1PR-independent signaling pathways that are distinct from the well-known immunosuppressive activity [39, 40]. Therefore, the development of anticancer agents without S1PR effect can be free from immunosuppression.

The spleen tissues of immunocompetent CD2F1 hybrid mice were obtained for H\&E staining and S1PR detection to address the effect on immune response. The spleen containsnon-lymphoid red pulp and lymphoid white pulp regions, mainly regulating erythrocyte disposal and antigens detect, respectively. Marginal zone, the region at the interface between red pulp and white pulp, traps particulate antigen from circulation and present to the lymphocytes of the spleen. Marginal zone B cells constitute a second major B cell population in the spleen. As a consequence, FTY720 at a six-hour treatment but not SPS-7 led to a profound depletion of marginal zone B cells (Figure 6A). Furthermore, FTY720 other than SPS-7 induced the down-regulation of S1P receptors (Figure 6A). The detection of circulating mature lymphocytes also showed that FTY720 but not SPS-7 induced a significant decrease in peripheral blood lymphocytes; more specifically, FTY720 significantly decreased T lymphocytes (Figure 6B). All together, it is indicative that FTY720 is an immunosuppressive agent. In contrast, SPS-7 at least at a short-term treatment shows little effect on modulating immune response.

\section{SPS-7 displays in vivo antitumor efficacy}

We subsequently carried out an in vivo study. The PC-3-derived cancer xenografts in nude mice were used as an in vivo model. As demonstrated in Figure 7, 
intraperitoneal (IP) administration of SPS-7 or FTY-720 caused a profound inhibition of tumor growth without a significant loss of body weight. The data also showed that the in vivo efficacy of SPS-7 was better than that of FTY720 (Figure 7).

A

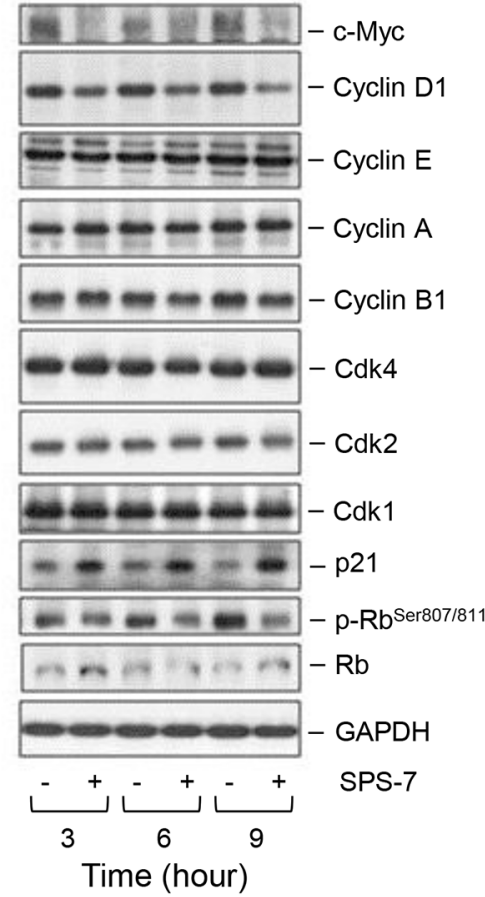

B

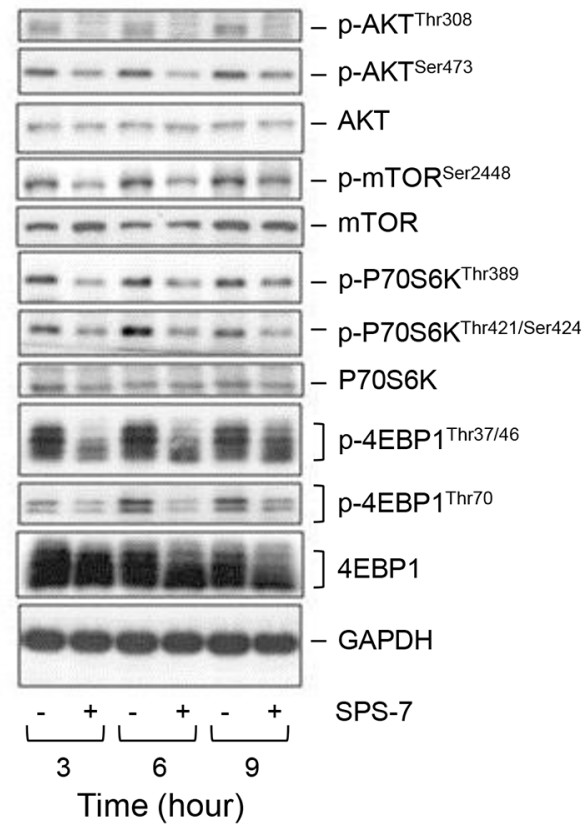

\section{DISCUSSION}

The U.S. Food and Drug Administration (FDA) have approved FTY720 as a firstline treatment in relapsing forms of multiple sclerosis. Recently, FTY720 has been
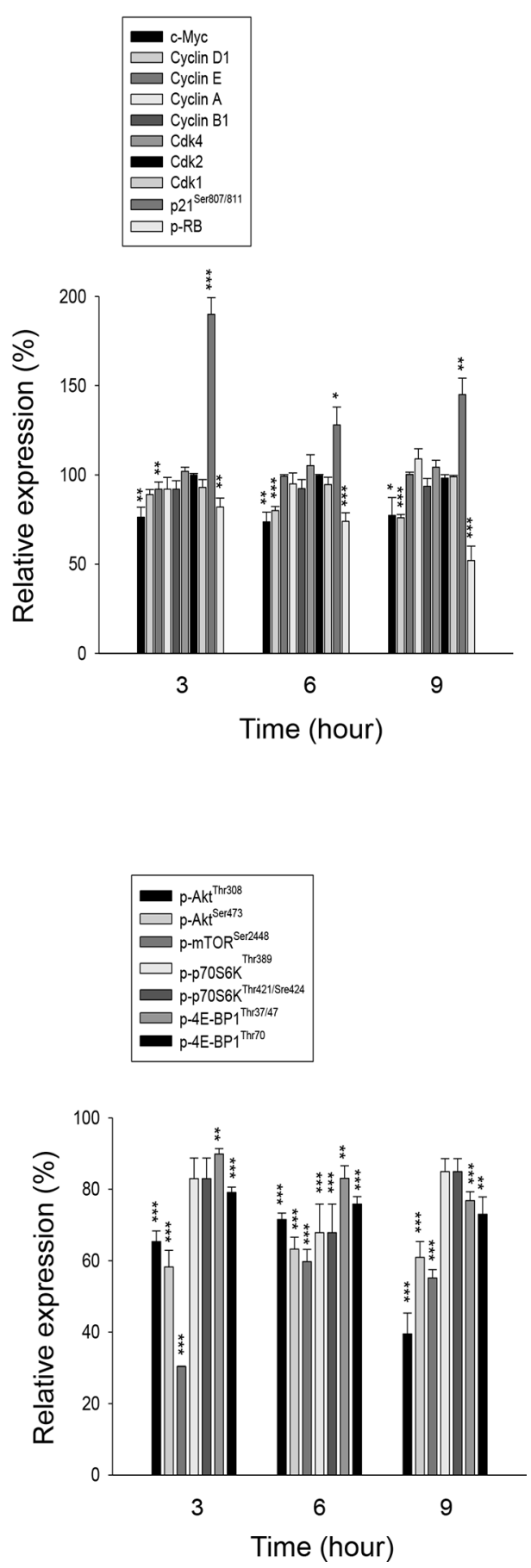

Figure 3: SPS-7 induces changes of expression levels of several proteins. PC-3 cells were incubated in the absence or presence of SPS-7 $(10 \mu \mathrm{M})$ for the indicated time. After the treatment, the cells were harvested and lysed for the detection of protein expressions of cell cycle regulators (A), and Akt/mTOR pathway signals (B) by Western blot analysis. The data are representative of three independent experiments. Data are expressed as mean \pm SEM of three determinations. ${ }^{*} P<0.05$, ${ }^{*} P<0.01$ and $* * * P<0.001$ compared with the control of $100 \%$. 

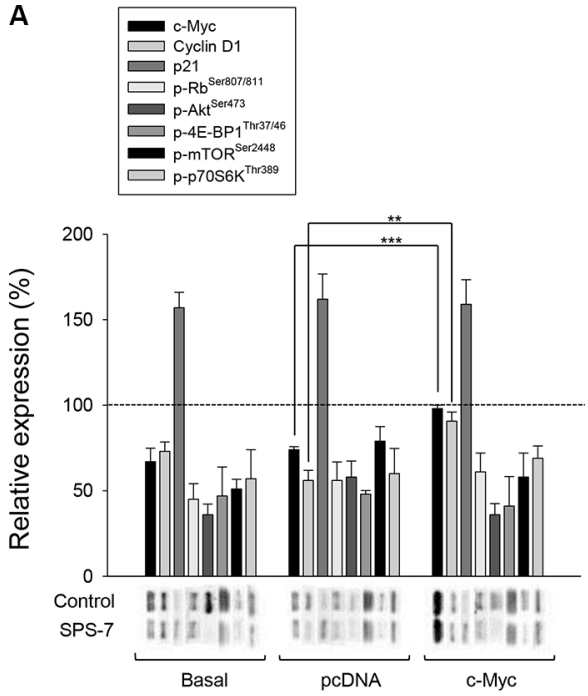

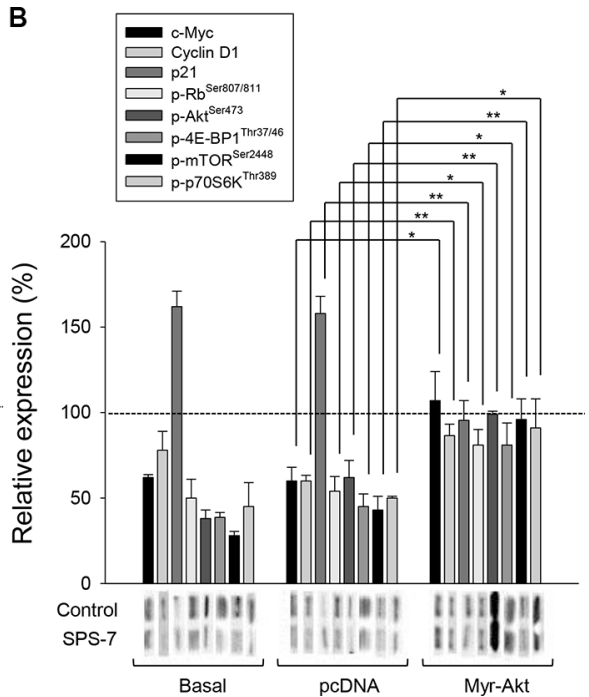

Figure 4: c-Myc and Akt involve in SPS-7-induced signaling pathways. PC-3 cells were transfected with c-myc plasmid (A) or Myr-Akt plasmid (B). Then, the cells were incubated in the absence or presence of SPS-7 $(10 \mu \mathrm{M})$ for nine hours. The cells were harvested and lysed for the detection of the indicated protein by Western blot analysis. The expression was quantified using the computerized image analysis system Image Quant (Amersham Biosciences). The data are expressed as mean \pm SEM of three to five independent experiments. $* P<0.05, * * P<0.01$ and $* * * P<0.001$.
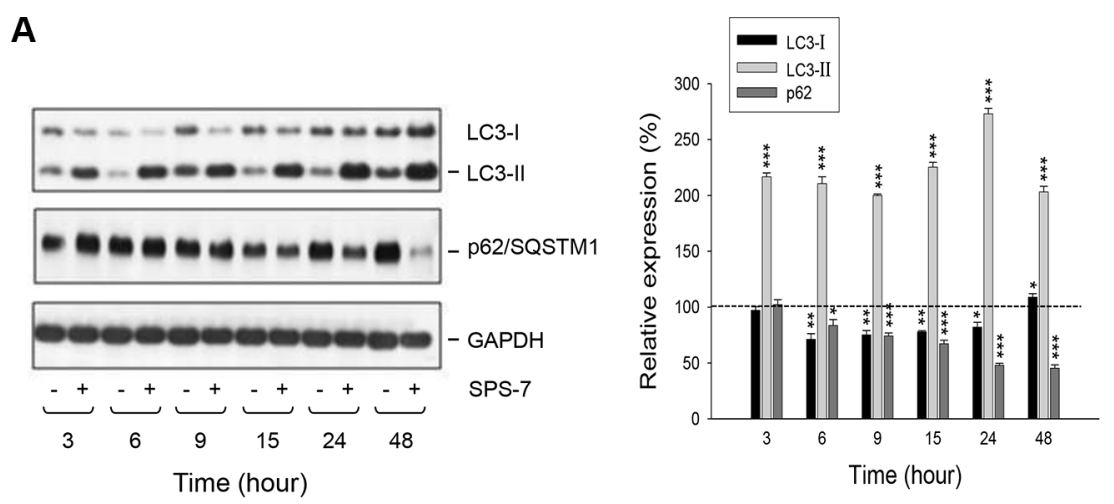

B

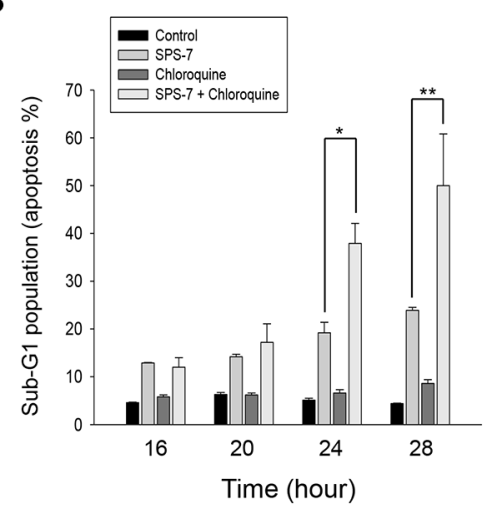

C
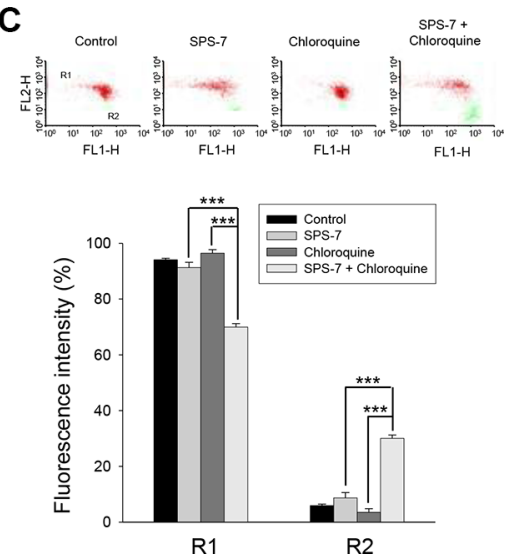

Figure 5: SPS-7 induces autophagy which counteracts apoptotic cell death. PC-3 cells were incubated in the absence or presence of (A) $10 \mu \mathrm{M}$ SPS-7 or (B, C) $10 \mu \mathrm{M}$ SPS-7 and/or $10 \mu \mathrm{M}$ chloroquine for the indicated time (A, B) or 24 hours (C). Cells were harvested and lysed for the detection of the indicated protein expression by Western blot analysis (A), or the cells were harvested for the detection of hypodiploid DNA content (apoptotic sub-G1 population) (B) or mitochondrial membrane potential (C) by flow cytometric analysis. Protein expression was quantified using computerized image analysis system ImageQuant (Amersham Biosciences, NJ, USA). Data are expressed as mean $\pm \mathrm{SEM}$ of three to five independent experiments. ${ }^{*} P<0.05, * * P<0.01$ and ${ }^{* * *} P<0.001$ compared with the control of $100 \%$. 
suggested to demonstrate anticancer properties in a variety of cancer cells through multiple pathways [11-18, 41, 42]. Of note, some of these pathways are unrelated to FTY720's phosphorylation and immunosuppressive effects. In recent decades, clinical substantiation has been obtained for the anticipation that anticancer treatments based on developing the host's own defense mechanism can be beneficial [43]. To this end, keeping anticancer properties
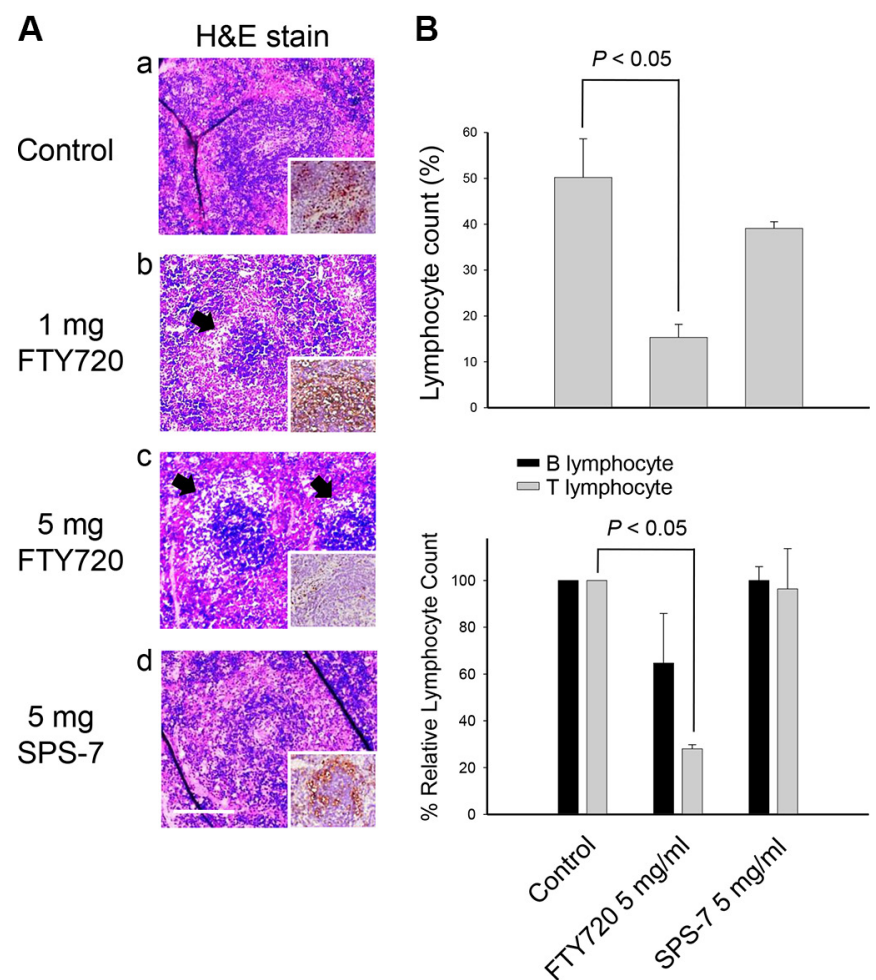

Figure 6: FTY720 but not SPS-7 induces immunosuppressive effect. CD2F1 mice were treated with or without intraperitoneal FTY720 or SPS-7 for 6 hours. Whole blood was collected and the spleens were dissected. (A) Splenic sections were fixed, embedded with paraffin and de-paraffinized for H\&E staining. IHC staining was used for detecting S1PR expression and performed by using UltraVision ${ }^{\mathrm{TM}}$ Quanto Detection System HRP DAB (Thermo Fisher Scientific, Waltham, MA, USA) (A, figure inset). (B) Blood lymphocyte count was performed using specific CD marker antibody conjugation and removal of erythrocytesas described in the Materials and Methods section. Then, lymphocyte count was determined by flow cytometric analysis (Becton Dickinson, Mountain View, CA). Data are expressed as mean \pm SEM of five independent experiments. $* P<0.05$ compared with the control.
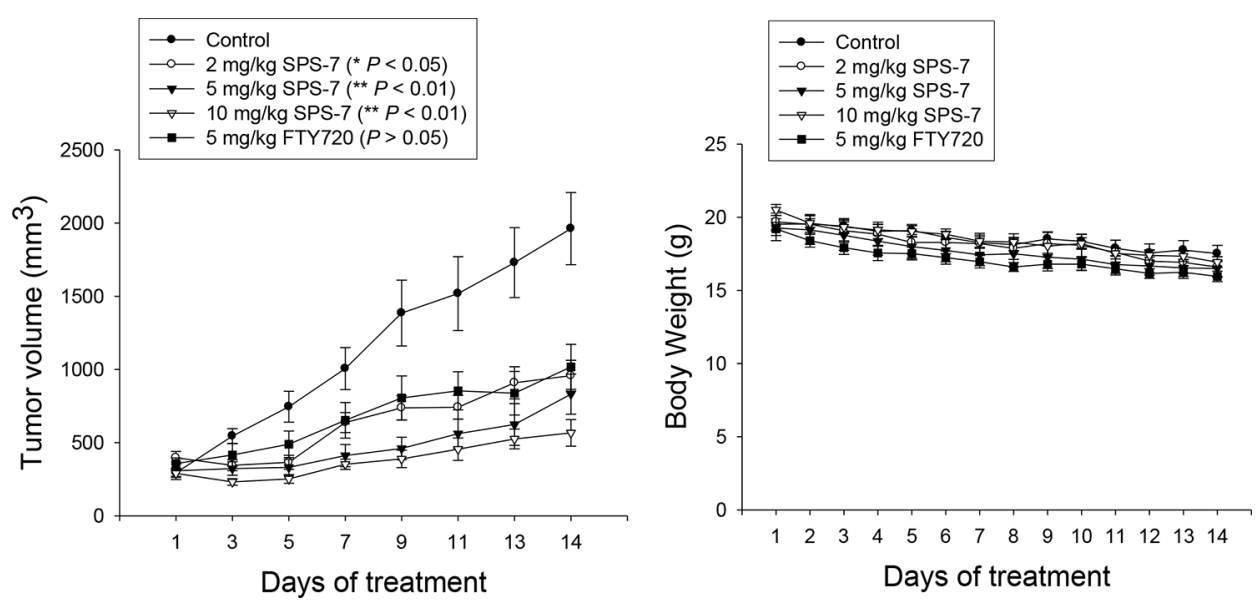

Figure 7: SPS-7 induces in vivo anti-tumor effect. The nude mice were subcutaneously injected with PC-3 cells ( $10^{7}$ cell/mouse). The tumors were measured every two days. When the tumors had reached a volume of 200 to $300 \mathrm{~mm}^{3}$, the mice were divided into five groups $(n=6)$, and vehicle, SPS-7 or FTY720 was given intraperitoneally every day. Data are expressed as mean \pm SEM of tumor size at indicated times post treatment with the compound. Weight change during treatment was also measured. 
but diminishing the immunosuppressive activities is highly anticipated in developing FTY720 analogues. Owing to a phenylene moiety in FTY720's side chain conferring potent immunosuppressive activity, compound structure modification by displacing the phenylene ring with other ring moiety has generated several series of derivatives with reduced immunosuppressive effects while improving anticancer activities. SPS-7 was generated by displacing the phenylene ring with a triazole and a side chain with an optimized length. SPS-7 exhibited higher anti-proliferative and apoptotic activities than FTY-720 in PC-3, DU-145 and $\mathrm{LNCaP}$ cells.

Lymphocyte circulation is dependent on cell surface expression of S1P receptor. Down-regulation of $\mathrm{S} 1 \mathrm{P}$ receptors in lymphocytes inhibits their exit from thymus and lymph nodes [44]. Splenic marginal zone B cells constitute a distinct naive B lymphoid lineage as a first line of defense against blood-borne pathogens [45]. They react to both thymus-dependent and -independent antigens, transport antigens to follicles to activate naive $\mathrm{T}$ cells and quickly differentiate into plasma cells, and initiate a rapid antibody response [45-48]. Depletion of these B cells can largely impair the related immune response and can be an indicator of immunosuppression. The data demonstrated that FTY720, but not SPS-7, induced the down-regulation of $\mathrm{S} 1 \mathrm{P}$ receptors, the depletion of marginal zone $\mathrm{B}$ cells and a significant decrease in peripheral blood lymphocytes, indicating that FTY720 other than SPS-7 is an immunosuppressant.

The regulation of cell cycle machinery and checkpoint signaling pathways has provided a variety of targets for novel antineoplastic agents [49]. mTOR regulates various components involved in protein synthesis, in particular at G1 phase, including initiation and elongation factors, and biogenesis of ribosomes themselves [29-33]. The data revealed that SPS-7 caused a profound inhibition of mTOR and related translational pathways, resulting in the down-regulation of cyclin D1 protein expression and G1 arrest of the cell cycle. Recent studies have documented the functional link between c-Myc and mTOR in regulating protein synthesis, suggesting that mTOR-dependent phosphorylation of 4E-BP1 is necessary to cancer cell survival in c-Mycdependent tumor initiation and maintenance [50]. Furthermore, in responding to oncogenic stimulation c-Myc may collaborate with $\mathrm{PI} 3 \mathrm{~K} / \mathrm{Akt}$ in regulating cyclin D1 expression [26, 28, 34]. Because coordination of c-Myc and PI3K/Akt not only accelerates tumor formation but also renders its progression to a more aggressive phenotype, targeting these molecules is considered as good strategy for cancer therapy. Overexpression of c-Myc or Myr-Akt (a constitutively active mutant of Akt) using plasmid-based gene transfer provided evidence showing that the inhibition of c-Myc expression was responsible for the down-regulation of cyclin D1 protein levels to SPS-7 action. Moreover, our discovery that Myr-Akt overexpression completely abolished SPS-7-induced effects suggested that Akt functioned upstream of c-Myc and mTOR translational pathways.

$\mathrm{PI} 3 \mathrm{~K} / \mathrm{Akt}$ is an early signaling molecule induced by growth factor receptor stimulation necessary for cell cycle entry and proliferation. PI3K/Akt activation occurs at immediate growth factor supplement and late G1 phase of the cell cycle. Similar to our work, multiple lines of evidence demonstrate that inhibition of late G1 PI3K/Akt activity leads to a decrease of c-Myc expression levels because of c-Myc destabilization [51]. Several signaling molecules through PI3K/Akt have been suggested to be involved in stabilizing c-Myc, including glycogen synthase kinase $3 \beta$, FoxO protein, NF- $\kappa \mathrm{B}$, signal transducer and activator of transcription 3 (STAT3) and mTOR [52, 53]. mTOR exists as two structurally distinct complexes, including the Akt substrate mTORC1 which regulating p70S6K and 4E-BP1/eIF4E, and mTORC2 which acting upstream of Akt $[30,31]$. Our study revealed that the antiproliferative and apoptotic effects of SPS-7 correlated with an inhibition of p70S6K and 4E-BP1 function, indicating that inhibition of cap-dependent protein synthesis directed the anticancer effect. Furthermore, c-Myc is short-lived with a half-life of 15 to $30 \mathrm{~min}$, requiring persistent synthesis for keeping protein levels such that the blockade of cap-dependent translation would rapidly decrease c-Myc protein levels. In support of these findings, it has been reported that certain dual targeted $\mathrm{PI} 3 \mathrm{~K} / \mathrm{mTOR}$ inhibitors efficiently killed primary c-Mycdriven B-cell lymphomas and human cell lines bearing IG-c-Myc translocations [54]. Altogether, our mechanistic interpretation offers a potential therapeutic opportunity for the treatment of HRPC with the inhibitor of PI3K/Akt/ mTOR/c-Myc signaling pathways.

Autophagy and apoptosis are two key cellular processes that regulate cell fate with complicated and interconnecting signaling crosstalk. It has been widely reported that they can regulate each other through signaling pathways that control both processes [35-37]. For example, p53 can simultaneously induce autophagy through increased expression of the effector DRAM (damageregulated autophagy modulator), a p53 target gene encoding a lysosomal protein that induces macroautophagy $[55,56]$. Furthermore, PI3K/Akt activation is a way to inhibit apoptosis andtoblock autophagy $[37,56]$. Several components of apoptosis and autophagy machinery can also regulate both processes, such as calpain, Fasassociated protein with death domain (FADD) and Bcl-2 family of proteins [56]. Our data showed that SPS-7 resulted in autophagic cellular program. Chloroquine, an inhibitor of autophagy, has been suggested to potentiate apoptotic cell death induced by various stimuli, indicating a cytoprotective role of autophagy. The data demonstrated that chloroquine significantly increased mitochondrial damage and apoptosis induced by SPS-7 suggesting that autophagy blunted SPS-7-induced anticancer effect. 
Taken together, the data suggest that SPS-7 is not an immunosuppressant while induces anti-proliferative and apoptotic signaling cascades against HRPC in a sequential manner (Figure 8). SPS-7 elicits an inhibitory effect on PI3K/ Akt activity, leading to the inhibition of mTOR signaling pathways and c-Myc down-regulation which in turn decrease cyclin D1 protein expression and induce G1 arrest of the cell cycle and apoptosis. However, SPS-7 also activates cytoprotective autophagy that blunts apoptosis. Combination of autophagy inhibitors may potentiate apoptosis induced by agents targeting $\mathrm{PI} 3 \mathrm{~K} / \mathrm{Akt} / \mathrm{mTOR} / \mathrm{c}-\mathrm{Myc}$ axis and provide novel strategy for the development of SPS-7.

\section{MATERIALS AND METHODS}

\section{Materials}

RPMI 1640 medium, antibodies to CD3e, PenStrep-Ampho Sol (10,000 U/ml of Penicillin, $10 \mathrm{mg} / \mathrm{ml}$ of Streptomycin, $0.025 \mathrm{mg} / \mathrm{ml}$ of Amphotericin B) and fetal bovine serum (FBS) were obtained from GIBCO/BRL Life Technologies (Grand Island, NY). Antibodies to caspase-7 and CD45RA, and BD Pharm Lyse ${ }^{\mathrm{TM}}$ lysing solution were from BD Transduction Laboratories (BD Bioscience,
San Jose, CA ). Flow cytometry staining buffer was from eBioscience (San Diego, CA). Antibodies to cyclin D1, cyclin $\mathrm{E}$, cyclin A, cyclin B1, cyclin-dependent kinase (Cdk) 4, Cdk2, Cdk1, Poly (ADP-ribose) polymerase (PARP), p21, CDC25A, $\alpha$-tubulin, Bcl-2, Bcl-xL, Mcl-1, Bak, Bid, Bax, Bad, LC-3, c-myc (N262), c-myc siRNA and HRP-conjugated anti-mouse and anti-rabbit IgGs were obtained from Santa Cruz Biotechnology, Inc. (Santa Cruz, CA). Antibody to S1PR was from GENETEX (Irvine,CA). Antibodies to $\mathrm{p}-\mathrm{RB}^{\mathrm{Ser} 801 / 811}$, caspase-9, caspase-7,

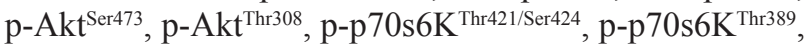
$\mathrm{p}-4 \mathrm{E}-\mathrm{BP} 1^{\mathrm{Th} 37 / 46}, \mathrm{p}-4 \mathrm{E}-\mathrm{BP} 1^{\mathrm{Thr} 70}$ and GAPDH were from Cell Signaling Technologies (Boston, MA). $\mathrm{NaHCO}_{3}$, dithiothreitol, phenylmethylsulfonylfluoride (PMSF), sulforhodamine B (SRB), propidium iodide (PI), trichloroacetic acid (TCA), thymine deoxyriboside, leupeptin, $\mathrm{NaF}, \mathrm{NaVO}_{4}$, chloroquine, Hank's balanced salt solution (HBSS) and all other chemical compounds were obtained from Sigma-Aldrich (St. Louis, MO). BioRed protein assay kit was from Bio-Red (Hercules, CA). Carboxyfluorescein succinimidyl ester (CFSE) was from Molecular Probes Inc. (Eugene, OR, USA).SPS compounds were synthesized and provided by our colleague (Dr. Duen-Ren Hou). The purity is more than $95 \%$ by the examination using HPLC and NMR.

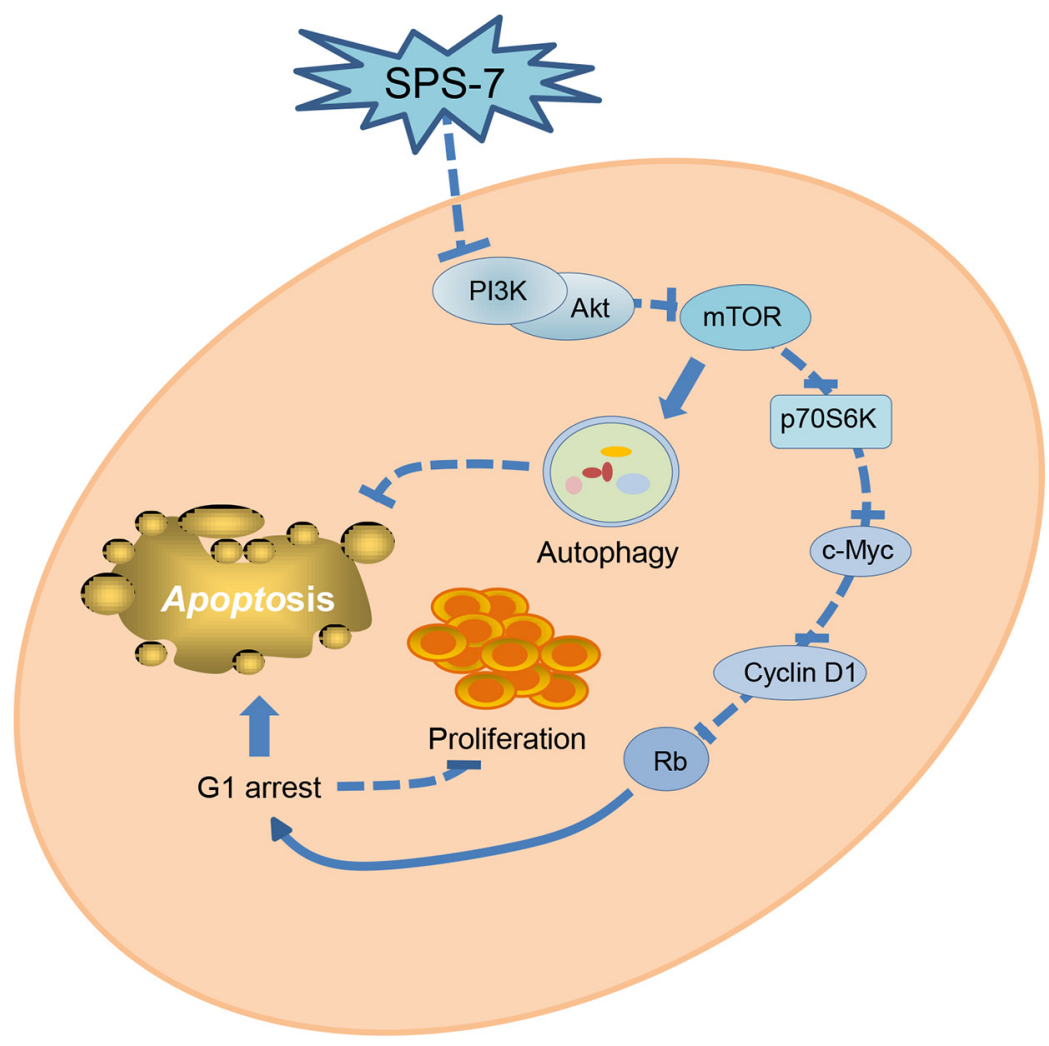

Figure 8: Schematic figure for SPS-7-mediated signaling pathways on the inhibition of cell proliferation and apoptosis induction. SPS-7 inhibits the activation of PI3K/Akt, which in turn inhibits mTOR signaling pathway and activation of c-Myc-cyclin $\mathrm{D} 1-\mathrm{Rb}$ axis, leading to G1 arrest of the cell cycle and apoptosis. SPS-7 also induces the activation of cytoprotective autophagy that partly blunts the apoptosis. Therefore, combination of autophagy inhibitors has been suggested on developing anticancer agents targeting PI3K/ Akt/mTOR pathways. 


\section{Tissue explants and cell culture}

All human tissue samples were obtained following informed consent of the donors and after fullreview by the Ethics Review Committee at National Taiwan University Hospital. The prostate specimens were from males by transurethral resection of the prostate. All patients with prostatism histories were diagnosed to have benign prostate hyperplasia by rectal digital examination, transrectal sonography of prostate and urodynamic studies. Isolation of human prostatic cells from prostatic tissue explants was described in the previous study [57]. Prostate cancer cell lines were from American Type Culture Collection (Rockville, MD). Cells were cultured in RPMI 1640 medium with $10 \%$ FBS $(v / v)$, penicillin (100 units/ml) and streptomycin $(100 \mu \mathrm{g} / \mathrm{ml})$. Cultures were maintained in a $37^{\circ} \mathrm{C}$ incubator with $5 \% \mathrm{CO}_{2}$.

\section{SRB assays}

Cells were seeded in 96-well plates in medium with $10 \%$ FBS. After 24 hours, cells were fixed with $10 \%$ TCA to represent cell population at the time of compound addition (TZ). After additional incubation of DMSO or the compound for 48 or $72 \mathrm{~h}, \mathrm{PC}-3$ or DU- 145 cells were fixed with $10 \%$ TCA and SRB at $0.4 \%(\mathrm{w} / \mathrm{v})$ in $1 \%$ acetic acid was added to stain cells. Unbound SRB was washed out by $1 \%$ acetic acid and SRB bound cells were solubilized with $10 \mathrm{mM}$ Tris base. The absorbance was read at a wavelength of $515 \mathrm{~nm}$. Using the following absorbance measurements, such as time zero (TZ), control growth (CTL), and cell growth in the presence of the compound (Tx), the percentage growth was calculated at each of the compound concentrations levels. Percentage growth inhibition was calculated as: [1-(Tx-TZ)/ $(\mathrm{CTL}-\mathrm{TZ})] \times 100 \%$. Growth inhibition of $50 \%\left(\mathrm{IC}_{50}\right)$ is determined at the compound concentration which results in $50 \%$ reduction of total protein increase in control cells during the compound incubation.

\section{Lymphocyte preparation and flow cytometry}

CD2F1 mice weighing 19 to $21 \mathrm{~g}$ were purchased from Lasco (BioLASCO Taiwan Co., Ltd). The mice were receiving intraperitoneal injection with FTY720, SPS-7 at 1 or $5 \mathrm{mg} / \mathrm{kg}$, or vehicle. After 6 hours, whole blood was collected from the heart of the mice into microtainer tube and lymph lymphocytes were harvested from the spleen. Mice spleenswere dissected on cold HBSS buffer with $10 \%$ FBS and scraped/smashed with a sterile tip on Falcon ${ }^{\circledR} 100 \mu \mathrm{m}$ cell strainers into homogenized suspension. All samples were stained with PE conjugated rat anti-mouse CD45RA (Clone 14.8) and FITC conjugated hamster anti-mouse CD3e (clone 145-2C11) molecular complex for 30 minutes in darkness. Then, all samples were prepared after removal of erythrocytes using
BD Pharm Lyse ${ }^{\mathrm{TM}}$ lysing solution (BD Bioscience, San Jose, CA ) for 15 to 60 minutes at room temperature in the dark. Finally, all samples were washed $1 \mathrm{X}$ flow cytometry staining buffer and determined by flow cytometric analysis (Becton Dickinson, Mountain View, CA).

\section{Hematoxylin and eosin $(\mathrm{H} \& \mathrm{E})$ and immunocytochemistry (IHC) staining}

After the treatment, mice splenic sections were fixed with $10 \%$ formalin for 24 hours and embedded with paraffin. Tissue sections $(7 \mu \mathrm{m})$ were deparaffinized with xylene and washed with PBS. H\&E staining was used for detecting marginal zone B cells. IHC staining was used for detecting S1PR expression and performed by using UltraVision ${ }^{\mathrm{TM}}$ Quanto Detection System HRP DAB (Thermo Fisher Scientific, Waltham, MA, USA). In brief, the sectionswere treated with Hydrogen Peroxide Block for 10 minutes and then Ultra $\mathrm{V}$ Block for 5 minutes. The sections were incubated with anti-rabbit S1PR antibody (1:200 dilutions) at $4{ }^{\circ} \mathrm{C}$ for 1 hour and washed with cold PBS for 5 minutes twice. Then, thesections were incubated with primary Antibody Amplifier Quanto, HRP Polymer Quanto, DAB QuantoChromogen and DAB Quanto Substrate, and were determined by chromogenic detection according to the manufacturer's instructions.

\section{Cell proliferation assay with CFSE labeling}

The cells were adjusted to a density of $10^{6}$ cells $/ \mathrm{ml}$ and were treated with CFSE at a final concentration of $10 \mu \mathrm{M}$. After incubation at $37^{\circ} \mathrm{C}$ for 10 minutes, labeling was blocked by the addition of RPMI medium with $10 \%$ FBS and then, ice-cold treated for 5 minutes. After centrifugation, the cells were seeded in RPMI medium with $10 \%$ FBS for 24,48 and 72 hours at $37^{\circ} \mathrm{C}$ under $5 \% \mathrm{CO}_{2} / 95 \%$ air. After the treatment, the fluorescence intensity was determined by flow cytometric analysis (Becton Dickinson, Mountain View, CA).The cell proliferation was to be followed by monitoring decrease in label intensity in successive daughter cell generations [58].The proliferation index and the cell populations of parent or different generations were calculated by Modfit LT Version 3.2 and WinList Version 5.0 software.

\section{Cell cycle synchronization}

Synchronization of thecells was performed by thymidine block. Briefly, cells were treated with $2 \mathrm{mM}$ thymidine in medium $/ 10 \%$ FBS for 24 hours. After washing cells with PBS, the block was released by the incubation of cells in fresh medium $/ 10 \%$ FBS (indicated as time zero), and cells were harvested at the indicated times. The cell-cycle progression was detected by flow cytometric analysis. 


\section{Flow cytometric analysis of PI staining}

After treatment, cells were harvested by trypsinization, fixed with $70 \%(v / v)$ alcohol at $4^{\circ} \mathrm{C}$ for 30 minutes and washed with PBS. The cells were centrifuged and resuspended with $0.5 \mathrm{ml}$ PI solution containing Triton X-100 $(0.1 \%, v / v)$, RNase $(100 \mu \mathrm{g} / \mathrm{ml})$ and PI $(80 \mu \mathrm{g} / \mathrm{ml})$. DNA content was analyzed with the flow cytometric analysis (Becton Dickinson, Mountain View, CA).

\section{Western blotting}

After the treatment, the cells were harvested with trypsinization, centrifuged and lysed in $0.1 \mathrm{ml}$ of lysis buffer containing $10 \mathrm{mM}$ Tris- $\mathrm{HCl}(\mathrm{pH} 7.4), 150 \mathrm{mM}$ $\mathrm{NaCl}, 1 \mathrm{mM}$ EGTA, 1\% Triton X-100, 1 mM PMSF, $10 \mu \mathrm{g} / \mathrm{ml}$ leupeptin, $10 \mu \mathrm{g} / \mathrm{ml}$ aprotinin, $50 \mathrm{mM} \mathrm{NaF}$ and $100 \mathrm{mM}$ sodium orthovanadate. Total protein was quantified, mixed with sample buffer and boiled at $90^{\circ} \mathrm{C}$ for 5 minutes. Equal amount of protein $(30 \mu \mathrm{g})$ was separated by electrophoresis in SDS-PAGE, transferred to PVDF membranes and detected with specific antibodies. The immunoreactive proteins after incubation with appropriately labeled secondary antibody were detected with an enhanced chemiluminescence detection kit (GE Healthcare Life Sciences, Buckinghamshire, UK).

\section{Measurement of mitochondrial membrane potential $\left(\Delta \Psi_{m}\right)$}

JC-1, a mitochondrial dye staining mitochondria in living cells in a membrane potential-dependent fashion, was used to determine $\Delta \Psi_{\mathrm{m}}$. Cells were treated with or without the compound. Thirty minutes before the termination of incubation, the cells were incubated with JC-1 (final concentration of $2 \mu \mathrm{M}$ ) at $37^{\circ} \mathrm{C}$ for 30 minutes. The cells were finally harvested and the accumulation of JC-1 was determined using flow cytometric analysis (Becton Dickinson, Mountain View, CA).

\section{Transient transfection}

The plasmids encoding c-Myc and Myr-Akt were used. For transfection, PC-3 cells were seeded into 60$\mathrm{mm}$ tissue culture dishes with $30 \%$ confluence and grown for 24 hours to about $50 \%$ confluence. Each dish was washed with serum-free Opti-MEM (Life Technologies, Grand Island, NY), and $2 \mathrm{ml}$ of the same medium was added. Aliquots containing expression vector or a control plasmid in serum-free Opti-MEM were transfected into cells using Lipofectamine 2000 (Invitrogen, Carlsbad, CA) following the manufacturer's instructions. After the incubation for 6 hours at $37^{\circ} \mathrm{C}$, cells were washed with medium and incubated in 10\% FBS-containing RPMI1640 medium for 48 hours. Then, the cells were treated with or without SPS-7. The Western blot analysis was performed.

\section{In Vivo antitumor models}

PC-3-derived cancer xenografts in nude mice were used as an in vivo model. The nude mice were subcutaneously injected with PC-3 cells ( $10^{7}$ cell/mouse). The tumors were measured every 2 days. When the tumors had reached a volume of 200 to $300 \mathrm{~mm}^{3}$, the mice were divided into five groups $(n=6)$ and the compound treatment was initiated. The compound was dissolved in $2 \%$ Tween 80 . Vehicle ( $2 \%$ Tween 80 ) or the compound was given intraperitoneally every day. The length (1) and width (w) of the tumor were measured every 2 days. The tumor volume was calculated as $1 \mathrm{w}^{2} / 2$. Animals were euthanized when a body weight loss of $15 \%$ at any time point or the tumor size reached $2000 \mathrm{~mm}^{3}$. The protocols of the in vivo study were approved by the Animal Care and Use Committee at National Taiwan University.

\section{Data analysis}

Data are presented as the mean \pm SEM for the indicated number of separate experiments. Statistical analysis of data for multiple groups is performed with oneway analysis of variance followed by Dunnett's multiple comparisons test. Single comparisons of appropriate groups were done with Student's $t$-test. $P$-values less than 0.05 are statistically considered significant.

\section{ACKNOWLEDGMENTS AND FUNDING}

We acknowledge the support provided by the Ministry of Science and Technology in Taiwan (MOST 103-2320-B-002-009-MY3 and MOST 104-2320-B-002005-MY3). The support by the Center for Innovative Therapeutics Discovery at National Taiwan University is also acknowledged.

\section{CONFLICTS OF INTEREST}

All authors declared no conflicts of interest.

\section{REFERENCES}

1. Drake CG, Sharma P, Gerritsen W. Metastatic castrationresistant prostate cancer: new therapies, novel combination strategies and implications for immunotherapy. Oncogene. 2014; 33:5053-5064.

2. Shtivelman E, Beer TM, Evans CP. Molecular pathways and targets in prostate cancer. Oncotarget. 2014; 5:7217-7259. doi: 10.18632/oncotarget.2406.

3. Elfiky AA, Jiang Z. The PI3 kinase signaling pathway in prostate cancer. Curr Cancer Drug Targets. 2013; 13:157-164.

4. Ellis L, Ku SY, Ramakrishnan S, Lasorsa E, Azabdaftari G, Godoy A, Pili R. Combinatorial antitumor effect of HDAC and the PI3K-Akt-mTOR pathway inhibition in a Pten deficient model of prostate cancer. Oncotarget. 2013; 4:2225-2236. doi: 10.18632/oncotarget.1314. 
5. Adhami VM, Syed DN, Khan N, Mukhtar H. Dietary flavonoid fisetin: a novel dual inhibitor of PI3K/Akt and mTOR for prostate cancer management. Biochem Pharmacol. 2012; 84:1277-1281.

6. Strub GM, Maceyka M, Hait NC, Milstien S, Spiegel S. Extracellular and intracellular actions of sphingosine-1phosphate. AdvExp Med Biol. 2010; 688:141-155.

7. Pitson SM. Regulation of sphingosine kinase and sphingolipid signaling. Trends Biochem Sci. 2011; 36:97-107.

8. Xia P, Wadham C. Sphingosine 1-phosphate, a key mediator of the cytokine network: juxtacrine signaling. Cytokine Growth Factor Rev. 2011; 22:45-53.

9. Gao Y, Gao F, Chen K, Tian ML, Zhao DL. Sphingosine kinase 1 as an anticancer therapeutic target. Drug Des Devel Ther. 2015; 9:3239-3245.

10. Chun J, Brinkmann V. A mechanistically novel, first oral therapy for multiple sclerosis: the development of fingolimod (FTY720, Gilenya). Discov Med. 2011; 12:213-228.

11. Hait NC, Avni D, Yamada A, Nagahashi M, Aoyagi T, Aoki H, Dumur CI, Zelenko Z, Gallagher EJ, Leroith D, Milstien S, Takabe K, Spiegel S. The phosphorylated prodrug FTY720 is a histone deacetylase inhibitor that reactivates ER $\alpha$ expression and enhances hormonal therapy for breast cancer. Oncogenesis. 2015; 4:e156.

12. Chien W, Sun QY, Lee KL, Ding LW, Wuensche P, TorresFernandez LA, Tan SZ, Tokatly I, Zaiden N, Poellinger L, Mori S, Yang H, Tyner JW, et al. Activation of protein phosphatase 2A tumor suppressor as potential treatment of pancreatic cancer. Mol Oncol. 2015; 9:889-905.

13. Lu Z, Wang J, Zheng T, Liang Y, Yin D, Song R, Pei T, Pan S, Jiang H, Liu L. FTY720 inhibits proliferation and epithelial-mesenchymal transition in cholangiocarcinoma by inactivating STAT3 signaling. BMC Cancer. 2014; 14:783.

14. Woo SM, Seo BR, Min KJ, Kwon TK. FTY720 enhances TRAIL-mediated apoptosis by up-regulating DR5 and down-regulating Mcl-1 in cancer cells. Oncotarget. 2015; 6:11614-11626. doi: 10.18632/oncotarget.3426.

15. Zheng $\mathrm{T}$, Meng X, Wang J, Chen X, Yin D, Liang Y, Song X, Pan S, Jiang H, Liu L. PTEN- and p53-mediated apoptosis and cell cycle arrest by FTY720 in gastric cancer cells and nude mice. J Cell Biochem. 2010; 111:218-228.

16. Zhang L, Wang HD, Ji XJ, Cong ZX, Zhu JH, Zhou Y. FTY720 for cancer therapy. Oncol Rep. 2013; 30:2571-2578.

17. Gräler MH. Targeting sphingosine 1-phosphate (S1P) levels and S1P receptor functions for therapeutic immune interventions. Cell Physiol Biochem. 2010; 26:79-86.

18. Rolin J, Sand KL, Knudsen E, Maghazachi AA. FTY720 and SEW2871 reverse the inhibitory effect of S1P on natural killer cell mediated lysis of K562 tumor cells and dendritic cells but not on cytokine release. Cancer Immunol Immunother. 2010; 59:575-586.

19. Lorvik KB, Bogen B, Corthay A. Fingolimod blocks immunosurveillance of myeloma and B-cell lymphoma resulting in cancer development in mice. Blood. 2012; 119:2176-2177.

20. Aguiar C, Batista S, Pacheco R. Cardiovascular effects of fingolimod: Relevance, detection and approach. Rev Port Cardiol. 2015; 34:279-285.

21. Ward MD, Jones DE, Goldman MD. Overview and safety of fingolimod hydrochloride use in patients with multiple sclerosis. Expert Opin Drug Saf. 2014; 13:989-998.

22. Adachi K, Chiba K. FTY720 story. Its discovery and the following accelerated development of sphingosine 1-phosphate receptor agonists as immunomodulators based on reverse pharmacology. Perspect Medicin Chem. 2007; $1: 11-23$.

23. Vigo E, Müller H, Prosperini E, Hateboer G, Cartwright $P$, Moroni M C, Helin K. CDC25A phosphatase is a target of $\mathrm{E} 2 \mathrm{~F}$ and is required for efficient E2F-induced S phase. Mol Cell Biol 1999; 19:6379-6395.

24. Cmielová J, Rezáčová M. p21Cip1/Waf1 protein and its function based on a subcellular localization. J Cell Biochem. 2011; 112:3502-3506.

25. Yoshida J, Ishibashi T, Nishio M. G1 cell cycle arrest by amlodipine, a dihydropyridine $\mathrm{Ca} 2+$ channel blocker, in human epidermoid carcinoma A431 cells. Biochem Pharmacol. 2007; 73:943-953.

26. Liao DJ, Thakur A, Wu J, Biliran H, Sarkar FH. Perspectives on c-Myc, Cyclin D1 and their interaction in cancer formation, progression, and response to chemotherapy. Crit Rev Oncog. 2007; 13:93-158.

27. Wang C, Lisanti MP, Liao DJ. Reviewing once more the c-myc and Ras collaboration: converging at the cyclinD1-CDK4 complex and challenging basic concepts of cancer biology. Cell Cycle. 2011; 10:57-67.

28. Leu WJ, Chang HS, Chan SH, Hsu JL, Yu CC, Hsu LC, Chen IS, Guh JH. Reevesioside A, a cardenolide glycoside, induces anticancer activity against human hormone-refractory prostate cancers through suppression of c-myc expression and induction of G1 arrest of the cell cycle. PLoS One. 2014; 9:e87323.

29. Polo ML, Riggio M, May M, Rodríguez MJ, Perrone MC, Stallings-Mann M, Kaen D, Frost M, Goetz M, Boughey J, Lanari C, Radisky D, Novaro V. Activation of PI3K/Akt/ mTOR signaling in the tumor stroma drives endocrine therapy-dependent breast tumor regression. Oncotarget. 2015; 6:22081-22097. doi: 10.18632/oncotarget.4203.

30. Sarbassov DD, Guertin DA, Ali SM, Sabatini DM. Phosphorylation and regulation of Akt/PKB by the rictormTOR complex. Science. 2005; 307:1098-1101.

31. Chiang GG, Abraham RT. Targeting the mTOR signaling network in cancer. Trends Mol Med. 2007; 13:433-442.

32. Lehman JA, Calvo V, Gomez-Cambronero J. Mechanism of ribosomal p70S6 kinase activation by granulocyte macrophage colony-stimulating factor in neutrophils: cooperation of a MEK-related, THR421/SER424 kinase and a rapamycin-sensitive, mTOR-related THR389 kinase. J Biol Chem. 2003; 278:28130-28138. 
33. Gingras AC, Gygi SP, Raught B, Polakiewicz RD, Abraham RT, Hoekstra MF, Aebersold R, Sonenberg N. Regulation of 4E-BP1 phosphorylation: a novel two-step mechanism. Genes Dev. 1999; 13:1422-1437.

34. Liao DJ, Thakur A, Wu J, Biliran H, Sarkar FH. Perspectives on c-Myc, Cyclin D1, and their interaction in cancer formation, progression, and response to chemotherapy. Crit Rev Oncog. 2007; 13:93-158.

35. Tang ZH, Zhang LL, Li T, Lu JH, Ma DL, Leung CH, Chen XP, Jiang HL, Wang YT, Lu JJ. Glycyrrhetinic acid induces cytoprotective autophagy via the inositol-requiring enzyme $1 \alpha$-c-Jun N-terminal kinase cascade in non-small cell lung cancer cells. Oncotarget. 2015; 6:43911-43926. doi: 10.18632/oncotarget.6084.

36. Viry E, Paggetti J, Baginska J, Mgrditchian T, Berchem G, Moussay E, Janji B. Autophagy: an adaptive metabolic response to stress shaping the antitumor immunity. Biochem Pharmacol. 2014; 92:31-42.

37. Radogna F, Dicato M, Diederich M. Cancer-type-specific crosstalk between autophagy, necroptosis and apoptosis as a pharmacological target. Biochem Pharmacol. 2015; 94:1-11.

38. Guerrero M, Urbano M, Roberts E. Sphingosine 1-phosphate receptor 1 agonists: a patent review (2013-2015). Expert Opin Ther Pat. 2016; 26:455-470.

39. Solary E, Bettaieb A, Dubrez-Daloz L, Corcos L. Mitochondria as a target for inducing death of malignant hematopoietic cells. Leuk Lymphoma. 2003; 44:563-574.

40. Kiyota M, Kuroda J, Yamamoto-Sugitani M, Shimura Y, Nakayama R, Nagoshi H, Mizutani S, Chinen Y, Sasaki N, Sakamoto N, Kobayashi T, Matsumoto Y, Horiike S, et al. FTY720 induces apoptosis of chronic myelogenous leukemia cells via dual activation of BIM and BID and overcomes various types of resistance to tyrosine kinase inhibitors. Apoptosis. 2013; 18:1437-1446.

41. Chua CW, Lee DT, Ling MT, Zhou C, Man K, Ho J, Chan FL, Wang X, Wong YC. FTY720, a fungus metabolite, inhibits in vivo growth of androgen-independent prostate cancer. Int J Cancer. 2005; 117:1039-1048.

42. Nagahara Y, Ikekita M, Shinomiya T. Immunosuppressant FTY720 induces apoptosis by direct induction of permeability transition and release of cytochrome $\mathrm{c}$ from mitochondria. J Immunol. 2000; 165:3250-3259.

43. Ehrke MJ. Immunomodulation in cancer therapeutics. IntImmunopharmacol. 2003; 3:1105-1119.

44. Sensken SC, Gräler MH. Down-regulation of S1P1 receptor surface expression by protein kinase $\mathrm{C}$ inhibition. J Biol Chem. 2010; 285:6298-6307.

45. Pillai S, Cariappa A, Moran ST. Marginal zone B cells. Annu Rev Immunol. 2005; 23:161-196.

46. Martin F, Oliver AM, Kearney JF. Marginal zone and B1 B cells unite in the early response against T-independent bloodborne particulate antigens. Immunity. 2001;14:617-629.
47. Carnrot C, Prokopec KE, Råsbo K, Karlsson MC, Kleinau S. Marginal zone B cells are naturally reactive to collagen type II and are involved in the initiation of the immune response in collagen-induced arthritis. Cell Mol Immunol. 2011; 8:296-304.

48. Shapiro GI, Harper JW. Anticancer drug targets: cell cycle and checkpoint control. J Clin Invest. 1999; 104:1645-1653.

49. Puigvert JC, Sanjiv K, Helleday T. Targeting DNA repair, DNA metabolism and replication stress as anti-cancer strategies. FEBS J. 2016; 283:232-245.

50. Pourdehnad M, Truitt ML, Siddiqi IN, Ducker GS, Shokat KM, Ruggero D. Myc and mTOR converge on a common node in protein synthesis control that confers synthetic lethality in Myc-driven cancers. Proc Natl Acad Sci USA. 2013; 110:11988-11993.

51. Kumar A, Marqués M, Carrera AC. Phosphoinositide 3-kinase activation in late $\mathrm{Gl}$ is required for c-Myc stabilization and S phase entry. Mol Cell Biol. 2006; 26:9116-9125.

52. Bouchard C, Marquardt J, Brás A, Medema RH, Eilers M. Myc-induced proliferation and transformation require Aktmediated phosphorylation of FoxO proteins. EMBO J. 2004; 23:2830-2840.

53. Han SS, Yun H, Son DJ, Tompkins VS, Peng L, Chung ST, Kim JS, Park ES, Janz S. NF-kappaB/STAT3/PI3K signaling crosstalk in iMyc E mu B lymphoma. Mol Cancer. 2010; 9:97.

54. Shortt J, Martin BP, Newbold A, Hannan KM, Devlin JR, Baker AJ, Ralli R, Cullinane C, Schmitt CA, Reimann M, Hall MN, Wall M, Hannan RD, et al. Combined inhibition of PI3K-related DNA damage response kinases and mTORC1 induces apoptosis in MYC-driven B-cell lymphomas. Blood. 2013; 121:2964-2974.

55. Crighton D, Wilkinson S, O'Prey J, Syed N, Smith P, Harrison PR, Gasco M, Garrone O, Crook T, Ryan KM. DRAM, a p53-induced modulator of autophagy, is critical for apoptosis. Cell. 2006; 126:121-134.

56. Thorburn A. Apoptosis and autophagy: regulatory connections between two supposedly different processes. Apoptosis. 2008; 13:1-9.

57. Guh JH, Hwang TL, Ko FN, Chueh SC, Lai MK, Teng CM. Antiproliferative effect in human prostatic smooth muscle cells by nitric oxide donor. Mol Pharmacol. 1998; 53:467-474.

58. Wallace PK, Muirhead KA. Cell tracking 2007: a proliferation of probes and applications. Immunol Invest. 2007; 36:527-561. 